\title{
EXCEL VBA ÜRLAP KIALAKÍTÁSA EGYMINTÁS T-PRÓBA KIÉRTÉKELÉSÉHEZ
}

\author{
Hampel György
}

\begin{abstract}
Absztrakt: A Microsoft Excel program Visual Basic for Applications szolgáltatásával kialakítottunk egy felhasználóbarát felületet egymintás t-próba elvégzésére. Így akár az Excel táblázatkezelő használatának ismerete nélkül is lehetőség van az egyik leggyakrabban megjelenő hipotézisvizsgálat, a t-próba elvégzésére. A használathoz elegendő megnyitni az elkészített alkalmazást, s a megjelenő ablakban a szükséges adatok és opciók beállítása után megkapjuk az eredményeket. A program vezérlőkkel biztosítja a könnyü kezelhetőséget, míg a müködést eseményvezérelt programozási technikával alakítottuk ki. Az eredményeket megkaphatjuk a betáplált minta adatsor alapján is, de a minta főbb jellemzői, az elemszám, az átlag és a szórás értékéből is. A vizsgálandó hipotézis megadásakor tetszőleges reláció alkalmazható, s ettől függően kétszélü vagy egyszélü eset egyikeként, automatikusan kapjuk meg az eredményeket. Az alkalmazás használatával matematikai statisztikai ismeretek és statisztikai programcsomag nélkül végezhetjük el az egymintás t-próbát.
\end{abstract}

\begin{abstract}
Using Visual Basic for Applications in Microsoft Excel, we designed a user-friendly interface for performing a one-sample t-test. Thus, even without knowledge of the use of the Excel spreadsheet, it is possible to perform one of the most common hypothesis tests, the t-test. All you have to do is open the completed application and in the window that appears, you will get the results after setting the required data and options. The program provides easy operation with controls, while the operation is designed with event-driven programming techniques. The results can be obtained from the data set of the fed sample, but also from the main characteristics of the sample, the number of items, the mean and the standard deviation. When specifying the hypothesis to be examined, any relation can be used, and depending on this, we obtain the results automatically as one of the doubleedged or single-edged cases. Using the application, we can perform the one-sample t-test without mathematical statistical knowledge and statistical software package.
\end{abstract}

Kulcsszavak: matematikai statisztika, egymintás t-próba, Excel VBA, programozás

Keywords: mathematical statistics, one-sample t-test, Excel VBA, programming

\section{Bevezetés}

Az informatikai eszközök térnyerésével folyamatosan több adat jelenik meg és tárolódik. Ezek feldolgozása, értelmezése és hasznosítása napjaink egyik nagy kihívása. Több publikáció jelent meg olyan alkalmazások fejlesztéséről, mely adatbázis szolgáltatásokat biztosít Access környezetben (Fabulya, 2018a; Fabulya, 2018b). Az adatok rendszerezett tárolása teszi lehetővé, hogy döntéseink adatokkal kellően alátámasztottak lehessenek. Sokszor matematikai statisztikai módszerek nélkülözhetetlenek az adatok kiértékeléséhez, melyhez kellő szakértelem szükséges még statisztikai programcsomag használata mellett is (Móri, 2011).

Célul tüztük ki, hogy a statisztikai kiértékelések elvégzését segítő alkalmazásokat fejlesszünk ki Microsoft Excel táblázatkezelővel, kihasználva annak programozhatósági lehetőségét a Visual Basic for Applications (VBA) szolgáltatást. Ennek keretében készítjük el az egyik legtöbbször alkalmazott hipotézisvizsgálat, az egymintás t-próba elvégzését megvalósító programunkat. Fontos szempont munkánk során, hogy olyan felületet alakítsunk ki a program használatához, mely nem igényel speciális jártasságot sem a számítógép kezelésében, sem a matematikai statisztika 
terén. Az Excel VBA használatával könnyen kialakíthatunk matematikai számításokat segítő alkalmazásokat (Fabulya, 2019), de akár dokumentumok generálását is VBA program végezheti (Fabulya, 2020).

A továbbiakban bemutatjuk a kutatás alapját biztosító egymintás t-próba elméleti ismereteit, valamint a VBA alkalmazott eszközeit, technikáit. Ezt követően részletesen ismertetésre kerül az elkészült program minden fontosabb eleme.

\section{Anyag és módszer}

\subsection{Az egymintás t-próba}

Az egymintás t-próbával egy normális eloszlású statisztikai sokaság várhatóértékére $(m)$ vonatkozó hipotézist tesztelhetjük egy, a sokaságból származó minta alapján. A t-próba végrehajtásakor elvégzendő számítás elméleti háttere azon alapul, hogy feltételezve a sokaság várhatóértéket a hipotézisben megjelenő értékünek $\left(m_{0}\right)$, ekkor a minta átlaga $(\bar{x})$ nagy valószínüséggel e feltételezett érték közelében lesz. Így a döntéskor csak kis valószínüséggel követünk el hibát akkor, amikor a feltételezett várhatóértéket nem tartjuk elfogadhatónak a minta átlagától való jelentős, szignifikáns eltérése miatt, pedig a várhatóérték ennek ellenére a feltételezett értékü. Vagyis elsőfajú hibát csak tetszőlegesen kis valószínüséggel követhetünk el, mert ezt az elsőfajú hibavalószínüséget $(\varepsilon)$ a próba végrehajtása elején magunk választhatjuk meg (Michaletzky-Mogyoródi, 1995).

A próba végrehajtásakor először formálisan egy nullhipotézist $\left(H_{0}\right)$ és egy alternatív hipotézist $\left(H_{1}\right)$ állítunk fel. A nullhipotézis mindig a várhatóérték $(m)$ egyenlőségét tartalmazza egy értékkel $\left(m_{0}\right)$, míg az alternatív hipotézis az egyenlőségtől eltérést három formában jelezheti, alkalmazkodva a vizsgálandó hipotézishez az 1. táblázat szerint.

\section{1. táblázat: Null és alternatív hipotézis}

\begin{tabular}{|c|c|c|}
\hline Vizsgálandó hipotézis & $H_{0}$ & $H_{1}$ \\
\hline$m=m_{0}$ & $m=m_{0}$ & $m \neq m_{0}$ \\
\hline$m \neq m_{0}$ & $m=m_{0}$ & $m \neq m_{0}$ \\
\hline$m>m_{0}$ & $m=m_{0}$ & $m>m_{0}$ \\
\hline$m<m_{0}$ & $m=m_{0}$ & $m<m_{0}$ \\
\hline$m \geq m_{0}$ & $m=m_{0}$ & $m<m_{0}$ \\
\hline$m \leq m_{0}$ & $m=m_{0}$ & $m>m_{0}$ \\
\hline
\end{tabular}

Forrás: a szerző saját szerkesztése.

A mintaelemek $\left(x_{i}\right)$ ismeretében kiszámítjuk az átlagot és a minta szórását az (l) és (2) képlet szerint.

$$
\bar{x}=\frac{1}{n} \sum_{i=1}^{n} x_{i}
$$


ahol:

$$
s=\sqrt{\frac{1}{n-1} \sum_{i=1}^{n}\left(x_{i}-\bar{x}\right)^{2}}
$$

$\bar{x}=$ a minta átlaga

$x_{i}=$ az i-edik mintaelem értéke

$n=$ a minta elemszáma

$s=$ a minta szórása

A hipotézisvizsgálat végén a döntést az alternatív hipotézis elfogadásáról, vagy elutasításáról két technikával végezhetjük, a kritikus tartománnyal, illetve a próba szignifikanciaszintjével. Ehhez elsőként ki kell számítani az egymintás t-próba statisztikai függvényének az értékét a (3) képlettel.

ahol:

$$
t=\frac{\bar{x}-m_{0}}{s} \cdot \sqrt{n}
$$

$t=$ a statisztikai függvény értéke

$\bar{x}=$ a minta átlaga

$m_{0}=$ a statisztikai sokaság feltételezett várhatóértéke

$n=$ a minta elemszáma

$s=$ a minta szórása

Mivel a statisztikai függvény értéke $(n-1)$ szabadságfokú t-eloszlást követ, ezért a kritikus tartomány határát, illetve a próba szignifikanciaszintjét a t-eloszlás eloszlásfüggvénye alapján kapjuk meg. A kritikus tartomány azon értékek intervalluma, melybe, ha a statisztikai függvény értéke tartozik, akkor az alternatív hipotézist fogadjuk el. A próba szignifikanciaszintje az a legnagyobb elsőfajú hibavalószínüség, melynél még a nullhipotézist fogadjuk el. Ezért, ha az elsőfajú hibavalószínüség nagyobb a próba szignifikanciaszintjénél, akkor az alternatív hipotézist fogadjuk el (Obádovics, 2020).

A (4) képlet mutatja az eloszlásfüggvény és a valószínüség közötti kapcsolatot. Egyúttal a képlet tekinthető a kvantilis definíciójának.

ahol:

$$
P\left(t<t_{p}\right)=F\left(t_{p}\right)=p
$$

$t=$ egy t-eloszlású valószínűségi változó értéke

$t_{p}=$ a t-eloszlás $p$ valószínüséghez tartozó kvantilise

$F=$ a t-eloszlás eloszlásfüggvénye

Amikor a döntést a kritikus tartomány alapján végezzük, akkor a statisztikai függvény kiszámított értékét ahhoz a kvantilishez viszonyítjuk, mely a kritikus tartomány határa. Ezért ez a kvantilis függ az elsőfajú hibavalószínüségtől és az 
alternatív hipotézistől. A próba szignifikanciaszintjének kiszámításának alapja a statisztikai függvény értéke, de az alternatív hipotézistől is függ. A döntésnél alkalmazott feltételt és a szignifikanciaszint kiszámítását a 2. táblázat tartalmazza.

2. táblázat: A döntés feltétele és a szignifikanciaszint kiszámítása

\begin{tabular}{|c|c|c|}
\hline $\mathrm{H}_{1}$ & $\begin{array}{l}\mathrm{H}_{1} \text { elfogadási feltétele } \\
\text { kritikus tartománnyal }\end{array}$ & Szignifikanciaszint $(\mathrm{p})$ \\
\hline $\mathrm{m} \neq \mathrm{m}_{0}$ & $|\mathrm{t}|>\mathrm{t}_{1-\frac{\varepsilon}{2}}$ & $\mathrm{p}=2 \cdot(1-\mathrm{F}(|\mathrm{t}|))$ \\
\hline $\mathrm{m}<\mathrm{m}_{0}$ & $\mathrm{t}<\mathrm{t}_{\varepsilon}$ & $\mathrm{p}=\mathrm{F}(\mathrm{t})$ \\
\hline $\mathrm{m}>\mathrm{m}_{0}$ & $\mathrm{t}>\mathrm{t}_{1-\varepsilon}$ & $\mathrm{p}=1-\mathrm{F}(\mathrm{t})$ \\
\hline
\end{tabular}

Forrás: a szerző saját szerkesztése.

\subsection{Az Excel VBA}

A Microsoft Excel táblázatkezelő program használatát, a szükséges számítások elvégzését, az eredmények megjelenítését egyedivé, felhasználóbaráttá és automatizálhatóvá tehetjük a Visual Basic for Applications (VBA) használatával (Matteson, 1995). A számítások kiinduló adatainak megadása és az eredmények megjelenítése nem csak a munkalapok celláival valósítható meg. Különböző vezérlöket alkalmazhatunk, melyeket elhelyezhetünk a munkalapokon, vagy ürlapokon (UserForm). Így magunk tervezhetjük meg a felhasználói felületet, melyen az adatbevitel, az eredmények megjelenítése és a számításokhoz szükséges opciók, beállítások az arra alkalmas vezérlőkkel megvalósíthatók. Eseményvezérelt programozási technika biztosítja, hogy a használat során a felhasználó tevékenységére reagáló viselkedést érjünk el. Ilyen felprogramozható esemény lehet klikkelés az egérrel egy parancsgombon, egy opció megváltoztatása, az adatbevitel végén az Enter leütése stb. Így például rögtön ellenőrizhetjük az adat helyességét, hiba esetén figyelmeztető üzenetet jeleníthetünk meg, blokkolhatunk tevékenységeket, amíg hibát detektálunk. A számítások végrehajtását programunk segítségével automatizálhatjuk, eredményeket írhat a programunk a munkalapokra, de a munkalapokon számított értékeket is feldolgozhatjuk (Kovalcsik, 2005).

Gyakrabban használt vezérlők:

- Ürlap (UserForm): A kezelőfelületet ablakként biztosítja, melyen további vezérlők helyezhetök el.

- Beviteli mező (TextBox): Elsődlegesen adat begépelésre kialakított vezérlő, de eredmény is megjeleníthető vele.

- Parancsgomb (CommandButton): Ráklikkelve kezdeményezhető valamilyen tevékenység végrehajtása.

- Jelölőnégyzet (CheckBox): Felirattal rendelkező vezérlö, melynek be- és kikapcsolt állapotát klikkeléssel egyszerüen beállíthatjuk.

- Választókapcsoló (OptionButton): Csoportosan alkalmazzuk, közülük csak egy lehet bekapcsolt állapotú.

- Listapanel (ListBox): Adatok listájának megjelenítését teszi lehetővé, de kijelölést is alkalmazhatunk a listában. 
- Legördülö lista (ComboBox): Legtöbbször arra használjuk, hogy kiválasszunk a listából egy elemet. Helytakarékos, mert csak a kiválasztott értéket mutatja, ha már választottunk a legördíthető listából.

- Felirat (Label): Feliratok megjelenítésére alkalmas. Így eredmények is kijelezhetők vele, mert a programunk megváltoztathatja a vezérlő által tárolt szöveget.

- Több oldal (MultiPage): Akkor célszerü alkalmazni, amikor sok vezérlő szükséges, ami miatt túl nagy lenne az ürlap. Lapozhatóan több oldalt biztosít a vezérlők elhelyezésére.

- Keret (Frame): Vezérlök csoportosítására használhatjuk, hogy rendszerezett, jobban áttekinthető ürlapot alakíthassunk ki.

A vezérlők tulajdonságokkal és metódusokkal rendelkező objektumok. A tulajdonságaik egy-egy értéket tárolnak, melyek meghatározzák a vezérlő megjelenését, viselkedését. A tulajdonságokat legtöbbször elöre, a program tervezési fázisában beállítjuk, de futási időben a programunk is módosíthatja öket. A vezérlők metódusai programok, melyeket futtatva valamilyen tevékenységet hajt végre a vezérlönk (Zimmerman, 1996).

\section{Eredmények és értékelésük}

A felhasználóbarát megjelenés és használat alapos tervezést igényel már az ürlap kialakításakor is. Az alábbi szempontokat tüztük ki a megvalósuló program tulajdonságaiként:

- A felhasználó minden szükséges tevékenységet egy ürlapon tudjon elvégezni. Az ürlap automatikusan jelenjen meg az Excel fájl megnyitásakor.

- Külön lap biztosítsa az adatbevitelt és az eredmények megjelenítését. Ezt MultiPage vezérlővel oldhatjuk meg. Így az eredmények kiszámítása csak akkor történik meg, amikor átlapozunk az adatbeviteli lapról az eredmények lapjára. Tehát parancsgomb sem szükséges a számítások végrehajtásához.

- Minden lehetséges adatból elvégezhető legyen a kiértékelés. A felhasználó tudja kiválasztani egy jelölőnégyzettel, hogy a minta adatsorán vagy a minta jellemzőin (elemszám, átlag, szórás) alapuljon a számítás.

- Bármilyen relációval megadható hipotézis kiértékelhető legyen. A lehetséges hipotézisek egyikének kiválasztását egy legördülő listából lehessen kiválasztani.

- A számítások egy Excel munkalapon, a felhasználótól rejtetten történjenek. Így nem kell a számításokat a programunknak tartalmaznia, csak az eredményeket kell átvenni a munkalapról, hogy az ürlapon jelenjenek meg.

\subsection{Az adatok megadásának felhasználói felülete}

$\mathrm{Az}$ egymintás t-próba kiértékelését végző program indításakor megjelenő felhasználói felületet az 1. ábrán láthatjuk. 


\section{1. ábra: A felhasználói felület}

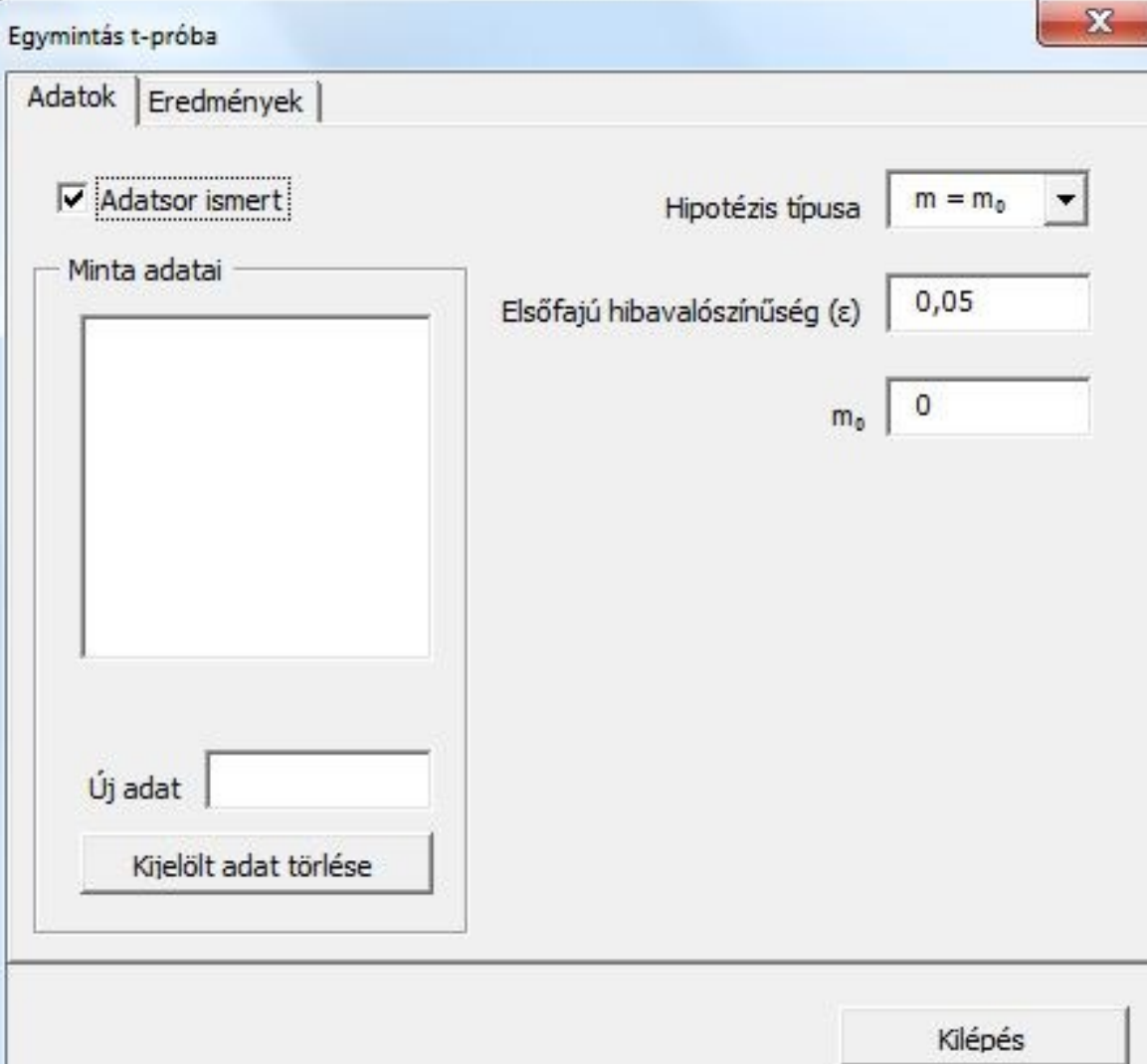

Forrás: a szerző saját szerkesztése.

Kezdetben az „Adatok” lapot használjuk. Az ürlap automatikus megjelenéséhez az Excel fájl megnyitásának eseményét kellett felprogramozni, mely az alábbi VBA kóddal történt.

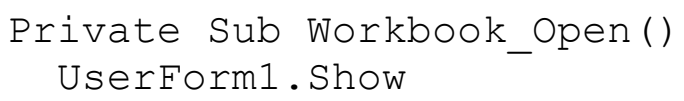

Az esemény (Workbook_Open) bekövetkezésekor egyetlen utasítás hajtódik végre a UserForm1 nevü ürlap vezérlő Show metódusa, mely megjeleníti az ürlapot. A jobb oldalon látható, hogy egy legördülő listából választhatjuk ki a hipotézis típusát, míg alatta egy-egy beviteli mező már alapértelmezett értékeket tartalmaz az elsőfajú hibavalószínüség és a feltételezett várhatóérték adataként. Ezek természetesen módosíthatók. 


\subsubsection{Ismert adatsor megadása}

Az ürlap bal oldalán egy jelölő négyzettel állíthatjuk be, hogy ismert adatsor esetén ez megadható legyen a „Minta adatai” feliratú keretben. Az új adat megadása beviteli mezővel történik. Felhasználóbarát megoldás, hogy az új adat begépelésének végén, az Enter leütésekor ellenőrzi a programunk az adat érvényességét. Ha nem tekinthető számnak az új adat, akkor hibaüzenetet kapunk (2. ábra), majd el kell végeznünk a javítást, hogy az érvényes adat bekerülhessen a felette megjelenő, kezdetben üres listába.

\section{2. ábra: Hibaüzenet egy adat esetén}

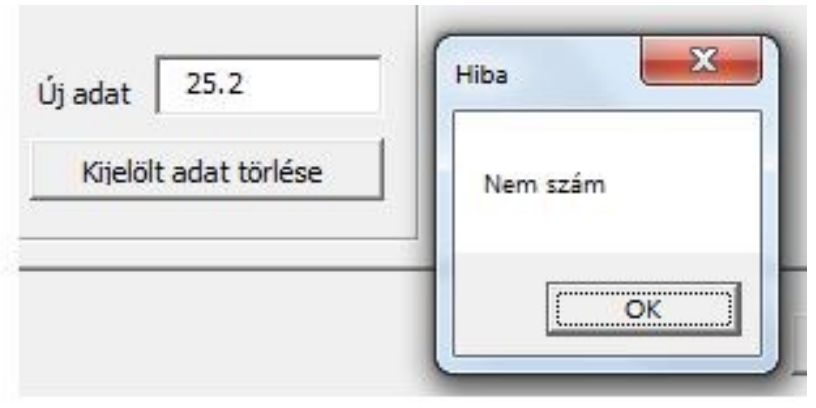

Forrás: a szerző saját szerkesztése.

A hiba ellenőrzését a beviteli mező billentyű leütés (TextBox1_KeyDown) eseményéhez rendeltük. A program VBA kódja az alábbi:

Private Sub TextBoxl_KeyDown (ByVal KeyCode

As MSForms.ReturnInteger, ByVal Shift As Integer)

If KeyCode $=13$ Then

ent $=$ True

If IsNumeric(TextBoxl.Text) Then

ListBox1.AddItem TextBox1. Text

TextBox1. Text $=" "$

TextBox1.SetFocus

Else

MsgBox "Nem szám", , "Hiba"

End If

End If

End Sulo

Csak Enter leütésekor (KeyCode = 13) kell ellenörizni, hogy a beviteli mezőben lévő adat (TextBox1. Text) számnak tekinthetö-e (IsNumeric). Ha igen, akkor az adat bekerül a listába (ListBox1.AddItem), majd kiürítjük a beviteli mezőt, hogy az újabb adat begépelését előkészítsük. Ha hibás az adat, akkor megjelenítjük a hibaüzenetet.

Az ent $=$ True értékadás jelzi, hogy az Enter billentyüt ütöttük le. Ez szintén a felhasználóbarát müködéshez kell, hogy meg tudjuk akadályozni, hogy egy másik vezérlöre térjen át a programunk. Ez bekövetkezne, ha programunk nem 
gondoskodna erről. Az alábbi programrész biztosítja, hogy folyamatosan gépelhessük be az újabb adatokat anélkül, hogy vissza kellene klikkelnünk a beviteli mezőbe:

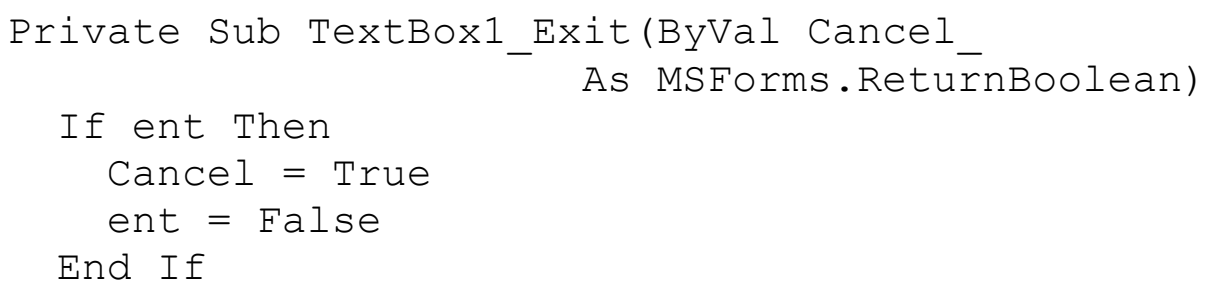

Tehát a TextBox1_Exit eseményét programoztuk fel úgy, hogy ha az Enter leütése miatt lépnénk ki a beviteli mezőböl, akkor a kilépést blokkoljuk (Cancel = True).

\subsubsection{Adatsor jellemzöinek megadása}

Ha a minta adatsora nem ismert, akkor a minta három jellemzőjének megadása szükséges az egymintás t-próba kiértékeléséhez. Kikapcsolva az „Adatsor ismert” jelölő négyzetet, az ürlapon a minta jellemzőit tudjuk begépelni egy-egy beviteli mezőben. Ez látható a 3. ábrán. Ekkor a „Minta jellemzői” feliratú keret jelenik meg a benne lévő vezérlőkkel, leváltva a „Minta adatai” keretünket. Ezt az alábbi programkód eredményezi:

Private Sub CheckBox1_Change()

Call kinezet

\section{End Sub}

Public Sub kinezet()

If CheckBoxl Then

Frame1.Visible = True

Frame2.Visible = False

Else

Frame1.Visible = False

Frame2.Visible = True

End If

End Sub

Tehát a jelölő négyzet megváltozásakor (CheckBox1_Change) meghívjuk a kinezet nevü eljárás végrehajtását, melyben a keret vezérlők láthatóságának tulajdonságát állítjuk át (Frame1.Visible és Frame2.Visible). Azért került mindez egy kinézetet beállító eljárásba, mert erre a változásra nem csak a jelölő négyzet megváltozásakor van szükség, hanem a kezdeti kinézet beállításakor is. 
3. ábra: A kitöltött adatok oldala

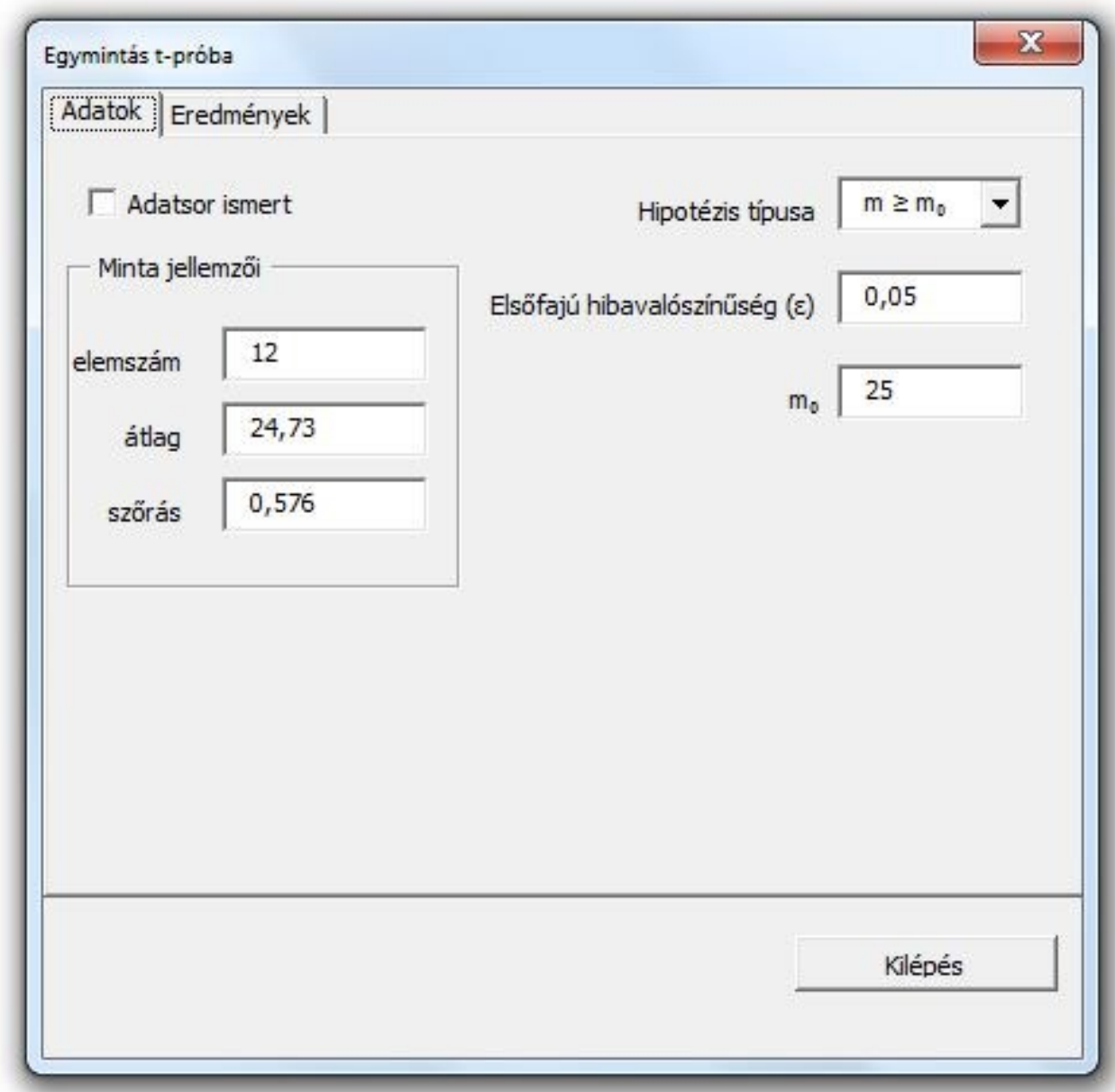

Forrás: a szerző saját szerkesztése.

\subsection{Az eredmények megjelenítése}

Az adatokat az ürlapon megadva, átlapozhatunk az „Eredmények” lapra. Ekkor az ürlapról az adatok átkerülnek a munkalap celláiba, hogy a munkalapon kiszámítódjon minden eredmény, melyet meg szeretnénk jeleníteni az ürlapon. A kód egy cella kitöltéséhez a következö:

$$
\text { Cells }(3,31)=\text { TextBox } 5 . \text { Text }
$$

Ekkor a munkalap 3. sorának 31. cellájába kerül a TextBox 5 beviteli mező adata. Az eredmények ürlapon megjelenítéshez még annyi szükséges, hogy a munkalapon kialakult eredményeket az ürlapon lévő felirat vezérlöbe helyezzük. Egy ilyen utasítás a következő:

Labe19. Caption $=\operatorname{Cells}(12,17)$. Text

Természetesen ilyen utasításból többre van szükség ahhoz, hogy minden eredmény az egyes cellákból egy-egy felirat vezérlőbe kerüljön. 
Az ürlapon nemcsak az eredmények jelennek meg, hanem rendszerezetten a legfontosabb adatokon túl a beálított hipotézis, valamint az egész mondatos válaszok is, ahogy a 4. ábrán látható.

\section{4. ábra: Az eredmények oldala}
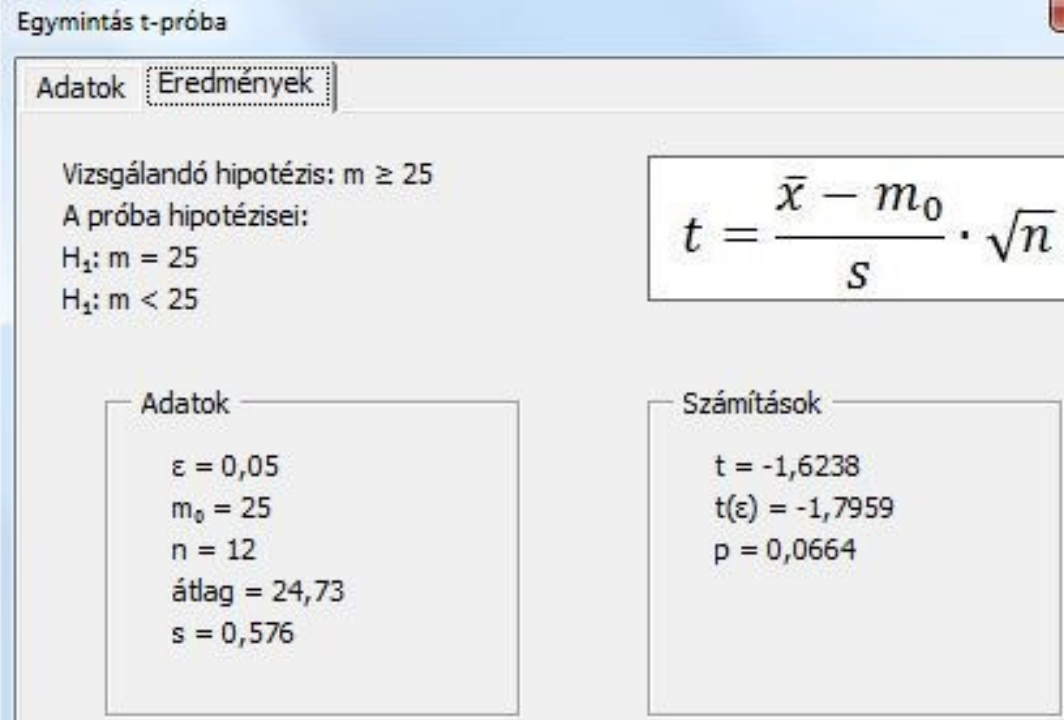

$$
\begin{aligned}
& H_{1} \text { elutasítva. ( } m<25 \text { hamis) } \\
& \varepsilon=0,05 \text { esetén az } m \geq 25 \text { elfogadható. } \\
& \text { A próba szignifikancia szintje: } p=0,0664
\end{aligned}
$$

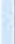

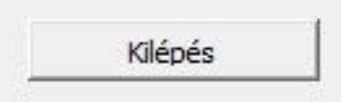

Forrás: a szerző saját szerkesztése.

Az ürlap bal felső részen először a vizsgálandó hipotézist látjuk, majd a t-próba nullhipotézisét és alternatív hipotézisét. A számítás legfontosabb képletét tájékoztatásként láthatjuk, mint díszítő elemet. A képlet kiszámításához szükséges adatok külön keretben kaptak helyet, mint ahogy a számítások végeredményei is. A statisztikai függvény értéke $(t)$ a munkalapon olyan formulával számítódott ki, mely hivatkozik az adatokat tartalmazó cellákra:

$=(\mathrm{AC} 4-\mathrm{AC} 6) / \mathrm{AC} 5 * \mathrm{AC} 3^{\wedge} 0,5$

A kritikus tartomány határának munkalap függvénye $(t(\varepsilon))$ :

$=\mathrm{T} \cdot \operatorname{INVERZ}(\mathrm{AC} 7 ; \mathrm{AC} 3-1)$

A szignifikanciaszint munkalap függvénye $(p)$ : $=\mathrm{T}$. ELOSZL $(\mathrm{AC} 8$; AC 3-1; IGAZ) 
A fenti formulákban a hivatkozott cellák jelentése:

AC3: a minta elemszáma $(n)$.

$\mathrm{AC} 4$ : a minta átlaga $(\bar{x})$.

AC5: a minta szórása $(s)$.

AC 6: a feltételezett várhatóérték $\left(m_{0}\right)$.

AC 7: az elsőfajú hibavalószínűség $(\varepsilon)$.

$A C 8$ : a statisztikai függvény értéke $(t)$.

Az alsó három sorban egészmondatos válaszokat is kap a felhasználó először az alternatív hipotézis megítéléséről (elutasítva), majd a vizsgálandó $(m \geq 25)$ hipotézis elfogadhatóságáról. Végül a szignifikanciaszint $(p)$ fontossága miatt ismét megjelenik.

\section{Következtetések}

A Microsoft Excel táblázatkezelő program Visual Basic for Applications szolgáltatásával úgy tudtuk kialakítani az egymintás t-próba kiértékelését végző programot, hogy a felhasználó speciális matematikai statisztikai ismeretek nélkül legyen képes használni egyetlen ürlapon, melyen az adatbevitel és az eredmények megjelenítése felhasználóbarát módon történik.

\section{Irodalomjegyzék}

Fabulya Z. (2018a): Access alkalmazás kialakítása ügyfélközpontú szolgáltatások nyilvántartására. Jelenkori Társadalmi és Gazdasági Folyamatok, 13 (1-2): 67-76.

Fabulya Z. (2018b): Access alkalmazás kialakítása dolgozói jelenlét nyilvántartására. Jelenkori Társadalmi és Gazdasági Folyamatok, 13 (1-2): 151-160.

Fabulya Z. (2019): Excel VBA függvények kialakítása háromdimenziós vektorok matematikai alkalmazására. Jelenkori társadalmi és gazdasági folyamatok, 14 (1-2): 29-34.

Fabulya Z. (2020): VBA program fejlesztése feladatsorok dokumentumainak generálására. Jelenkori társadalmi és gazdasági folyamatok, 14 (3-4): 139-143.

Kovalcsik G. (2005): Az Excel programozása. Computerbooks, Budapest.

Matteson B. L. (1995): Microsoft Excel Visual Basic Programmer's Guide. MicrosoftPress, Washington.

Michaletzky Gy., Mogyoródi J. (1995): Matematikai statisztika. Nemzeti Tankönyvkiadó, Budapest.

Móri T. (2011): Statisztikai hipotézisvizsgálat. Typotex Kft., Budapest.

Obádovics J. Gy. (2020): Valószínüségszámítás és matematikai statisztika. Scolar Kiadó Kft., Budapest. ISBN: 9789632440675

Zimmerman M. W. (1996): Microsoft Office 97 Visual Basic Programmer's Guide. MicrosoftPress, Washington. 